\title{
Cerebral aneurysms in pediatrics: a case report and review of the literature
}

\author{
Antonio Heredia-Gutiérrez ${ }^{1 *}$ and María E. Carbarín-Carbarín ${ }^{2}$ \\ ${ }^{1}$ Servicio de Neurocirugía Pediátrica; ${ }^{2}$ Unidad de Terapia Intensiva Pediátrica. Hospital para el Niño Poblano, San Andrés Cholula, Puebla, Mexico
}

\begin{abstract}
Background: Cerebral aneurysms in pediatrics represent $<4 \%$ of the total of this condition, and their rupture represents 10-23\% mortality. Aneurysms have been associated with infections, head injuries, sickle cell anemia, cardiovascular diseases, autoimmune diseases, immunodeficiencies, and connective tissue diseases. Their clinical presentation includes severe headache, seizures, motor-sensory deficits, and death due to subarachnoid and intraparenchymal hemorrhage. Case report: We describe the case of a 12-year-old female patient who presented with a sudden intense headache; after 72 hours, generalized tonic-clonic seizures were observed. At the hospital, she was stabilized with antiepileptic drugs and analgesics. A simple head computed tomography scan showed intraparenchymal hemorrhage in the right frontal lobe and subarachnoid hemorrhage. The study was complemented with a cerebral angiotomography, which revealed an aneurysm of the anterior communicating artery. The pediatric neurosurgeon evaluated the case, and management in the pediatric intensive care unit was decided. Two weeks after the stroke, the aneurysm was clipped and excluded. The patient developed adequate clinical evolution and resolution of initial symptoms, resuming her daily activities. Conclusions: Pediatric cerebral aneurysms differ from their adult counterparts, mainly in their etiology and evolution. In addition, pediatric patients have a longer life expectancy. Aneurysm clipping and neurological endovascular therapy have shown similar results.
\end{abstract}

Keywords: Cerebral aneurysm. Pediatrics. Aneurysm clipping. Endovascular therapy.

\section{Aneurismas cerebrales en pediatría: reporte de un caso y revisión de la literatura}

\section{Resumen}

Introducción: Los aneurismas cerebrales en pediatría representan menos del $4 \%$ del total de estos padecimientos, aunque su rotura tiene una mortalidad del $10-23 \%$. Se han asociado con infecciones, traumatismos craneoencefálicos, anemia de células falciformes, enfermedades cardiovasculares, enfermedades autoinmunitarias, inmunodeficiencias y enfermedades del tejido conectivo. Su presentación clínica se manifiesta con cefalea intensa, crisis convulsivas, déficit motor-sensitivo y muerte debida a la hemorragia subaracnoidea e intraparenquimatosa. Caso clínico: Se describe el caso de una paciente de 12 años que presentó cefalea súbita intensa; a las 72 horas se agregaron crisis convulsivas tónico-clónicas generalizadas. En el hospital se estabilizó con fármacos antiepilépticos y analgésicos. Se le realizó una tomografía de cráneo simple que evidenció hemorragia intraparenquimatosa en el lóbulo frontal derecho y hemorragia subaracnoidea. El estudio se complementó con una angiotomografía cerebral, la cual reveló un aneurisma de la arteria comunicante anterior. Fue valorada por

\section{Correspondence:}

${ }^{*}$ Antonio Heredia-Gutiérrez

E-mail: antonhered@yahoo.com (http://creativecommons.org/licenses/by-nc-nd/4.0/)
Available online: 16-12-2021 Bol Med Hosp Infant Mex. 2021;78(6):636-641

www.bmhim.com 
el neurocirujano pediatra y se decidió su manejo en la unidad de terapia intensiva pediátrica. A las 2 semanas de iniciado el evento se realizó clipaje y exclusión del aneurisma. La paciente tuvo una adecuada evolución clínica y resolución de los síntomas iniciales, retomando sus actividades de la vida diaria. Conclusiones: Los aneurismas cerebrales en pediatría difieren de su contraparte en los adultos, principalmente en su etiología y evolución, ya que los pacientes pediátricos tienen mayor expectativa de vida. El clipaje del aneurisma y la terapia endovascular neurológica han mostrado resultados similares.

Palabras clave: Aneurisma cerebral. Pediatría. Clipaje de aneurisma. Terapia endovascular.

\section{Introduction}

Internationally, cerebral aneurysms in pediatrics represent $<4 \%$ of all aneurysms $s^{1,2}$, and their rupture has a mortality rate of $10-23 \%$. They have been associated with infections, traumatic brain injury (TBI), sickle cell anemia, cardiovascular diseases, autoimmune diseases, immunodeficiencies, connective tissue diseases, dysmorphic syndromes, and family history of aneurysms. The clinical presentation is due to subarachnoid and intraparenchymal hemorrhage and the mass effect caused by the size of the aneurysm, which can produce severe headaches, seizures, disorientation, motor-sensory deficit, and even death. Diagnosis is made by cranial computed tomography angiography (CTA), cerebral magnetic resonance angiography (MRA), and, ideally, with four-vessel cerebral digital subtraction angiography (DSA) $)^{3,4}$.

Aneurysms should be considered as one of the differential diagnoses in patients with the described clinical manifestations and associated pathologies for prompt diagnosis and treatment.

\section{Clinical case}

We describe the case of a 12-year-old female patient who presented with a sudden intense headache while at home and without exertion. She was initially managed with oral paracetamol at home, and after 72 hours, she developed generalized tonic-clonic seizures and was transferred to the hospital, where she was stabilized with antiepileptics and analgesics. She immediately underwent a simple cranial tomography, which showed an intraparenchymal hemorrhage within the right frontal lobe and a subarachnoid hemorrhage in the interhemispheric fissure. The study was complemented with a CTA, showing a $12 \mathrm{~mm}$ bilobed saccular aneurysm in the anterior communicating artery, so she was evaluated by the pediatric neurosurgeon (Figure 1).

The patient was awake, with a tendency to somnolence, reactive isochoric pupils $(3 \mathrm{~mm})$, without cranial nerve involvement, left body hemiparesis with strength $4 / 5$. She presented the following scores: on the Glasgow
Coma Scale, 12 points (O3, V4, M5); on the World Federation of Neurologic Surgeons scale (WFNS), grade IV; on the Hunt and Hess scale, grade 3, and on the Fisher scale, grade 4 (by tomography). Management was decided in the Pediatric Intensive Care Unit (PICU) to ensure stability, and clipping of the aneurysm was performed by right pterional craniotomy two weeks after the event (Figure 2). The patient was extubated 72 hours after the procedure and subsequently returned to the ward for continued management.

On day 7, a postoperative CTA was performed, which showed adequate clipping and exclusion of the aneurysm (Figure 3). The patient was evaluated by Rheumatology, Cardiology, Neurology, Infectology, and Genetics, performing whole body CTA, echocardiography, bilateral renal ultrasound, and immunological tests. However, it was not possible to identify the etiology of the aneurysm. She was discharged on postoperative day 8 with an antiepileptic drug and resolution of symptoms. She is currently asymptomatic with outpatient follow-up.

\section{Discussion}

Aneurysms are classified according to their size and morphology and can be single or multiple in $10 \%$ of cases. By size, they are small $(<5 \mathrm{~mm})$, large $(6-24 \mathrm{~mm})$, or giant $(>25 \mathrm{~mm})$. Morphologically, they are saccular and fusiform or dissecting. Their location has a predilection for the anterior circulation in $75 \%$ of cases, with the internal carotid artery, middle cerebral artery, and anterior cerebral artery being the most frequent locations, and the posterior circulation in $25 \%$, most commonly in the basilar artery. The location and size are similar in pediatric and adult patients ${ }^{1,5}$.

In pediatric patients, aneurysm etiology is identified in $<50 \%$ of the cases; $5-10 \%$ are associated with TBI, $15 \%$ with infections, and $50 \%$ with vascular dissection. TBI-associated aneurysms cause a lesion of the three vascular layers, producing pseudoaneurysms and true aneurysms. Those related to infections (generally by Staphylococcus aureus, Streptococcus viridans, and 

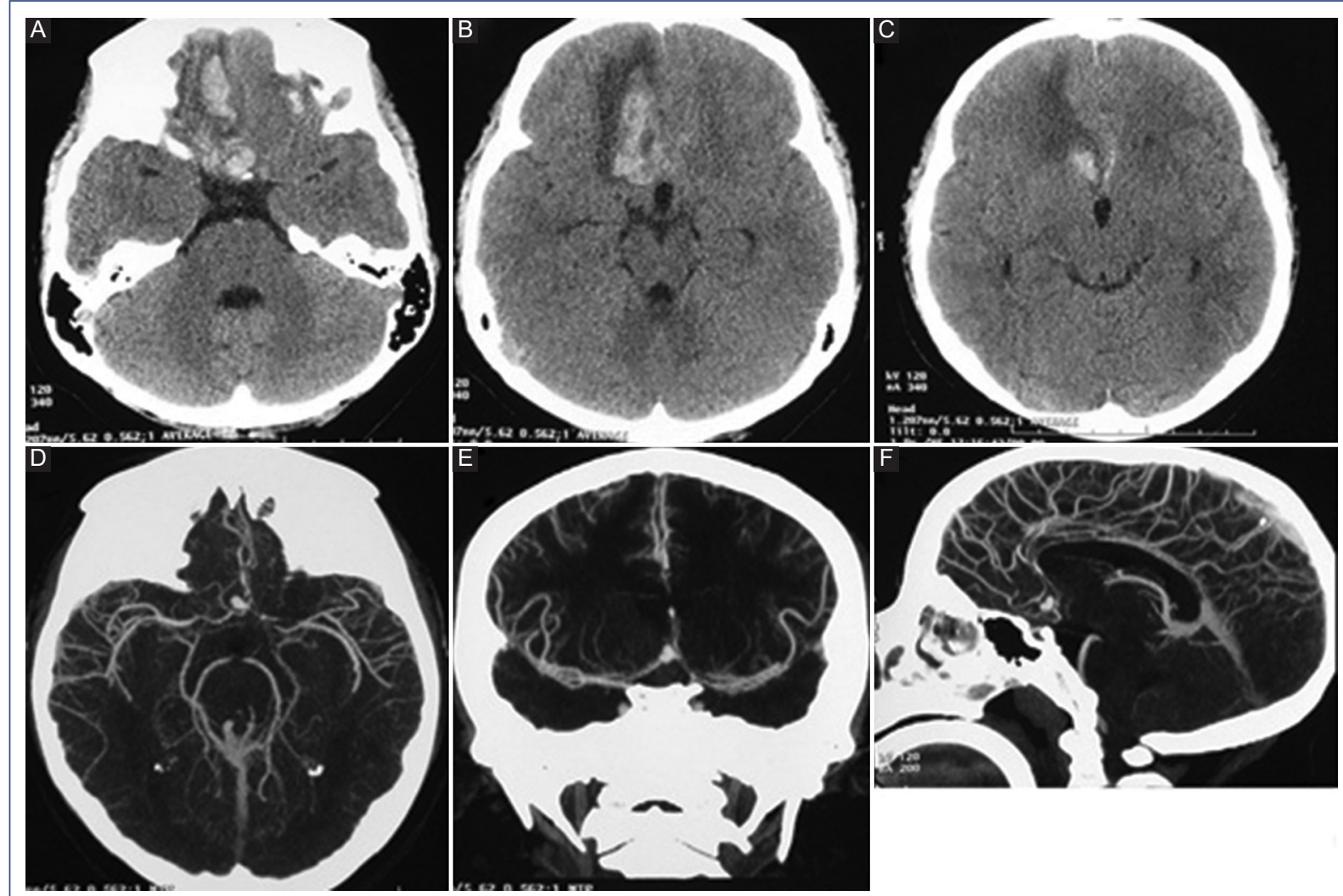

Figure 1. A-C: Axial section of the simple cranial tomography showing a hemorrhage in the medial side of the right frontal lobe. D-F: Axial, coronal, and sagittal tomography-angiography showing bilobed aneurysm of the anterior communicating artery.

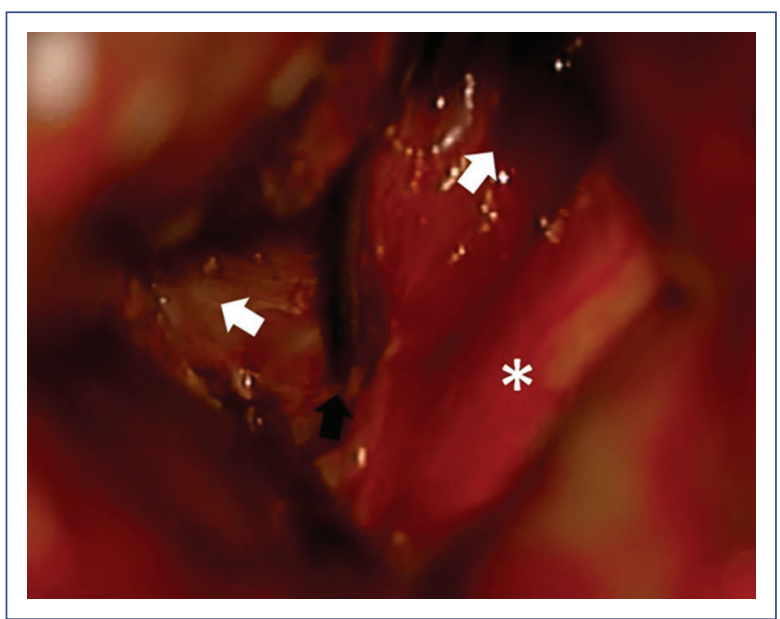

Figure 2. Intraoperative image showing the bilobed suprachiasmatic aneurysm. The optic chiasm (asterisk), the transient clip (black arrow), and the lobes of the aneurysm with anterior and superior projection (white arrows) are observed.

other Gram-negative microorganisms) show vasculitis and consequent weakening of the vascular wall.
Dissecting aneurysms are caused by endothelial injury and transmural vascular dissection that weakens the muscular and adventitial layer. They are associated with medical-genetic diseases (polycystic kidney disease, aortic coarctation, aortic valve stenosis, moyamoya disease, sickle cell anemia, Kawasaki syndrome, Takayasu disease, human immunodeficiency virus (HIV), tuberous sclerosis, neurofibromatosis type 1, Ehler-Danlos syndrome, and Marfan syndrome) $)^{3,5}$.

In adults, aneurysms develop near a vascular bifurcation point, where the endothelium is damaged, there is a thinning or absence of the muscular layer, and, frequently, there is fibrinoid material in the adventitial layer. These lesions are favored by alcohol abuse, smoking, aging, systemic arterial hypertension, and several medical (aortic aneurysm, aortic valve stenosis, aortic coarctation, Ehler-Danlos syndrome, fibromuscular dysplasia, among others) and genetic (hereditary hemorrhagic telangiectasia, intracranial arteriovenous malformation, Klinefelter syndrome, Marfan syndrome, neurofibromatosis, Noonan syndrome, pheochromocytoma, polycystic kidney disease, 


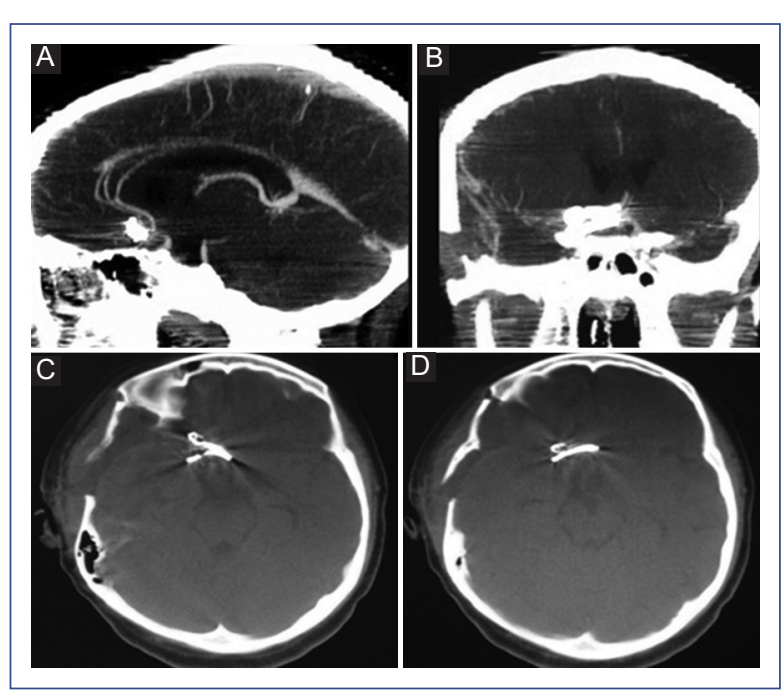

Figure 3. A, B: Sagittal and coronal sections of tomographyangiography show adequate exclusion of the aneurysm and permeability of the anterior cerebral arteries and their branches. C, D: Simple axial skull tomography (bone window) shows the position of vascular clips in the aneurysm.

tuberous sclerosis, alpha-1 antitrypsin deficiency, and alpha-glucosidase deficiency) conditions. Alcoholism, smoking, and hypertension are rare conditions in the pediatric population ${ }^{2,6}$.

DSA is the gold standard for diagnosing aneurysms; however, it is increasingly common to use CTA and MRA, which have detected aneurysms larger than

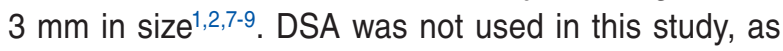
neurological endovascular therapy (NET) was not considered the first treatment line.

Ruptured cerebral aneurysms present high morbidity and mortality. Management by surgical clipping or NET should be performed once diagnosed. However, vasospasm and cerebral edema may limit such management. Therefore, the recommendations are to operate in the first 72 hours of the event or wait until cerebral edema decreases to favor microsurgical management and also in cases with poor neurological status. These recommendations are based on the adult population. In the case of multiple aneurysms, Burkhardt et al. proposed clipping the ruptured aneurysm first and then waiting up to 30 days to treat the rest, with no impact on the patient ${ }^{10}$. There is no consensus on the timing of surgery in the pediatric population. Unlike adults, in whom vasospasm is the leading cause of death, vasospasm is tolerated in children due to leptomeningeal circulation and higher cerebral blood flow, allowing more time to reduce cerebral edema and facilitate exposure of the aneurysm for clipping 2,3,6,11.

Aryan et al. conducted a study of 50 patients with aneurysms, in which clipping was performed in $78.8 \%$, all in the anterior circulation, and NET was used in $21.2 \%$ located in the posterior circulation ${ }^{12}$. Additionally, Sanai et al. reported similar results with both techniques in 32 patients: clipping was performed in $40 \%$ and NET in $60 \%$, but they found residual aneurysm or recurrence in $19 \%$ of the NET group and no recurrence in the clipping group ${ }^{13}$.

Lasjaunias et al. conducted a study in 59 patients with aneurysms, in which they embolized (68.8\%), clipped $(21.9 \%)$, or used combined treatment in $9.3 \%$ of cases. These authors observed complete exclusion of the aneurysm in patients who underwent clipping and recurrence of $8.3 \%$ in those who underwent embolization ${ }^{14}$. Furthermore, in a study of 22 patients, Proust et al. performed clipping in $77.3 \%$, NET in $18.2 \%$, and combined therapy in $4.5 \%$; in the patients in whom clipping was performed, the aneurysms were located in the anterior circulation ${ }^{15}$. In a series of 22 patients with aneurysms, $77 \%$ located in the anterior circulation and $23 \%$ in the posterior circulation, Slator et al. embolized $80 \%$ and performed clipping in $20 \%$, without finding statistically significant differences between the treatments used ${ }^{16}$. In another case series of 6 patients $<1$ year of age with giant aneurysms, Ren $\mathrm{Y}$ et al. recommended clipping since it allows draining the intraparenchymal hematoma, excluding the aneurysm and removing the mass effect, a situation not offered by NET. However, they recognize that NET produces less bleeding than clipping ${ }^{17}$.

Garg et al. treated 62 patients with aneurysms: $51.6 \%$ underwent clipping, 30.6\% underwent NET, $6.4 \%$ underwent another type of treatment (bypass or ligation of the main aneurysm artery), and $9.6 \%$ underwent conservative management; $1.6 \%$ died before surgery. Of the aneurysms, $3.2 \%$ were of infectious origin, and another $3.2 \%$ were post-traumatic. The authors found no differences between the clipping group and the NET group, and patients did not have recurrence either; they mentioned that the treatment decision was influenced by its cost since clipping is less expensive than $\mathrm{NET}^{18}$. Requejo et al. treated 17 patients with aneurysms: 23.5\% underwent clipping, $64.7 \%$ underwent NET, $5.8 \%$ were managed conservatively, and the other $5.8 \%$ died before surgical management. The authors reported similar results with NET and clipping ${ }^{19}$. Of 10 patients with aneurysms, Thioub et al. performed 
clipping in 7 and NET in one. One of the patients died during anesthetic induction, and another did not accept surgical management. Also, one aneurysm was of traumatic origin and four with possible infectious origin. The authors recommend clipping when socioeconomic conditions are unfavorable ${ }^{20}$. llovar et al. treated eight patients with cerebral aneurysms: one underwent clipping, four underwent NET, and three were managed conservatively (two incidental and one symptomatic), concluding that endovascular and microsurgical management are similar ${ }^{21}$.

In two international trials, Molyneux et al. ${ }^{22,23}$ demonstrated that clipping offers more prolonged survival and a lower risk of rebleeding than NET in managing cerebral aneurysms.

Four cases of aneurysms in pediatric patients have been reported in Mexico: Mercado et al. reported the case of a 14-year-old male patient with a posterior communicating artery aneurysm and aortic coarctation resolved with $\mathrm{NET}^{24}$. Martinez-Longoria et al. reported the second case: a 12-year-old female patient with HIV and a fusiform aneurysm of the right internal carotid artery associated with vasculitis. The patient was managed conservatively and presented remission of the aneurysm at 6 months ${ }^{25}$. Palomera Gómez et al. reported the case of a 10-year-old female patient with a large aneurysm of the right carotid apex ${ }^{26}$. Finally, Escobar-de la Garma et al. reported the case of an 11-year-old male patient with a small aneurysm of the left internal carotid artery bifurcation ${ }^{27}$. These last two cases were resolved with clipping of the aneurysm.

In conclusion, pediatric cerebral aneurysms differ from their adult counterparts mainly in their etiology and evolution. Although aneurysm clipping and NET have shown similar results, more recommendations are still needed to choose the best option in children. Due to a longer life expectancy, pediatric patients should be offered the best therapeutic option.

\section{Ethical disclosures}

Protection of human and animal subjects. The authors declare that no experiments were performed on humans or animals for this study.

Confidentiality of data. The authors declare that they have followed the protocols of their work center on the publication of patient data.

Right to privacy and informed consent. The authors have obtained the written informed consent of the patients or subjects mentioned in the article. The corresponding author has this document.

\section{Conflicts of interest}

The authors declare no conflict of interest.

\section{Funding}

None.

\section{Acknowledgments}

We want to thank Dr. Ámbar Heredia Gutiérrez for her critical review of the article and her suggestions.

\section{References}

1. Amelot A, Saliou G, Benichi S, Alias Q, Boulouis G, Zerah M, et al. Longterm outcomes of cerebral aneurysms in children. Pediatrics. 2019:143:e20183036.

2. Texakalidis P, Sweid A, Mouchtouris N, Peterson EC, Sioka C, Rangel-Castilla $\mathrm{L}$, et al. Aneurysm formation, growth, and rupture: the biology and physics of cerebral aneurysms. World Neurosurg. 2019;130:27784.

3. Beez T, Steiger HJ, Hänggi D. Evolution of management of intracranial aneurysms in children: a systematic review of the modern literature. J Child Neurol. 2016;31:773-83.

4. Yao Z, Li J, He M, You C. Intracranial aneurysm in patients with sickle cell disease: a systematic review. World Neurosurg. 2017;105:302-13.

5. Krings T, Geibprasert S, terBrugge KG. Pathomechanisms and treatment of pediatric aneurysms. Childs Nerv Syst. 2010;26:1309-18.

6. Toth G, Cerejo R. Intracranial aneurysms: review of current science and management. Vasc Med. 2018;23:276-88.

7. Chen X, Liu Y, Tong H, Dong Y, Ma D, Xu L, et al. Meta-analysis of computed tomography angiography versus magnetic resonance angiography for intracranial aneurysm. Medicine (Baltimore). 2018;97:e10771.

8. D'Andrea G, Picotti V, Familiari P, Barbaranelli C, Frati A, Raco A. Impact of early surgery of ruptured cerebral aneurysms on vasospasm and hydrocephalus after $\mathrm{SAH}$ : our preliminary results. Clin Neurol Neurosurg. 2020;192:105714.

9. Dundar TT, Aralasmak A, Kitiș S, Yılmaz FT, Abdallah A. Comparison of subtracted computed tomography from computed tomography perfusion and digital subtraction angiography in residue evaluation of treated intracranial aneurysms. World Neurosurg. 2019;132:e746-51.

10. Burkhardt JK, Winkler EA, Weller J, Lawton MT. Early versus delayed microsurgical clipping of additional unruptured aneurysms in patients with aneurysmal subarachnoid hemorrhage. World Neurosurg. 2020:142:e233-e237.

11. Yang M, Wang S, Zhao $Y$, Zhao J. Management of intracranial aneurysm in children: clipped and coiled. Childs Nerv Syst. 2008;24:1005-12.

12. Aryan HE, Giannotta SL, Fukushima T, Park MS, Ozgur BM, Levy ML. Aneurysms in children: review of 15 years experience. J Clin Neurosci. 2006;13:188-92.

13. Sanai N, Auguste KI, Lawton MT. Microsurgical management of pediatric intracranial aneurysms. Childs Nerv Syst. 2010;26:1319-27.

14. Lasjaunias $P$, Wuppalapati $S$, Alvarez H, Rodesch G, Ozanne A. Intracranial aneurysms in children aged under 15 years: review of 59 consecutive children with 75 aneurysms. Childs Nerv Syst. 2005;21:437-50.

15. Proust F, Toussaint P, Garniéri J, Hannequin D, Legars D, Houtteville JP, et al. Pediatric cerebral aneurysms. J Neurosurg. 2001;94:733-9.

16. Slator N, Talibi SS, Mundil N, Thomas A, Lamin S, Walsh R, et al. Paediatric intracranial aneurysms: a British institutional review. Childs Nerv Syst. 2019;35:1197-1205.

17. Ren Y, Zhao S, Liu L, Sun H, Liu Y, Li H, et al. Successful microsurgical treatment of intracranial aneurysms in infants: a retrospective study and literature review. Acta Neurochir (Wien). 2018;160:783-92.

18. Garg K, Singh PK, Sharma BS, Chandra PS, Suri A, Singh M, et al. Pediatric intracranial aneurysms-our experience and review of literature. Childs Nerv Syst. 2014;30:873-83.

19. Requejo F, Ceciliano A, Cardenas R, Villasante F, Jaimovich R, Zuccaro G. Cerebral aneurysms in children: are we talking about a single pathological entity? Childs Nerv Syst. 2010;26:1329-35.

20. Thioub M, Mbaye M, Thiam AB, Mutomb S, Sy C, Faye M, et al. Pediatric intracranial aneurysms in Senegal: a series of 10 cases treated in unfavorable socioeconomic conditions. Childs Nerv Syst. 2019;35:165-8. 


\section{A. Heredia-Gutiérrez, M.E. Carbarín-Carbarín: Cerebral aneurysms in pediatrics}

21. llovar S, Benedik MP, Vesnaver TV, Osredkar D. Brain aneurysms in the pediatric population of Slovenia: a case series. Neuropediatrics. 2019;50:188-92.

22. Molyneux AJ, Kerr RS, Birks J, Ramzi N, Yarnold J, Sneade M, et al. Risk of recurrent subarachnoid haemorrhage, death, or dependence and standardised mortality ratios after clipping or coiling of an intracranial aneurysm in the International Subarachnoid Aneurysm Trial (ISAT): long-term follow-up. Lancet Neurol. 2009;8:42733.

23. Molyneux AJ, Birks J, Clarke A, Sneade M, Kerr RS. The durability of endovascular coiling versus neurosurgical clipping of ruptured cerebra aneurysms: 18-year follow-up of the UK cohort of the International Subarachnoid Aneurysm Trial (ISAT). Lancet. 2015;385:691-7.
24. Mercado R, López S, Cantú C, Sánchez A, Revuelta R, Gómez-Llata S, et al. Intracranial aneurysms associated with unsuspected aortic coarctation. J Neurosurg. 2002;97:1221-5.

25. Martínez-Longoria CA, Morales-Aguirre JJ, Villalobos-Acosta CP, Gómez-Barreto D, Cashat-Cruz M. Occurrence of intracerebral aneurysm in an HIV-infected child: a case report. Pediatr Neurol. 2004;31:130-2.

26. Palomera-Gómez HG, Uribe-Olalde JS, Alcántara-Gómez LA, Zambrano-Velarde LE, Gómez-Limón E, González-Plascencia EA, et al. Aneurismas del ápex carotideo en la edad pediátrica. Reporte de un caso. Bol Med Hosp Infant Mex. 2013;70:387-91.

27. Escobar-de la Garma VH, De Montesinos-Sampiedro A, Padilla-Vázquez F, Ramírez-Aguilar R, Mendizábal-Guerra R. Aneurismas intracraneanos en la infancia. Arch Neurocien (Mex). 2013;18:211-5. 